\title{
MORPHOLOGICAL AND HISTOCHEMICAL ASPECTS OF THE EPIDIDYMAL REGION AND DUCTUS DEFERENS OF COLUMBINA TALPACOTI (TEMMINCK) (COLUMBIDAE, COLUMBIFORMES)
}

\author{
Sandra Maria das Graças Maruch ${ }^{1}$ \\ Maria das Graças Ribeiro ${ }^{1}$ \\ Maria Eloiza de Oliveira Teles ${ }^{1}$
}

\begin{abstract}
The Columbina talpacoti (Temminck, 1811) dove, a small bird of the order Columbiformes, is abundant throughout Brazil and interacts closely with city inhabitants. This study describes the morphological and histochemical aspects of the epididymal region and ductus deferens of this species, comparing them with those of other bird species studied. It is believed that a better understanding of the reproductive biology of Columbina talpacoti could help to solve the ecological and sanitary problems involving these birds.

KEY WORDS. Columbidae, Columbiformes, male genital, epididymis, efferent ductuli, ductus deferens
\end{abstract}

Most of the reports available in the literature on the morphology of the male genital system of birds refer to the domestic fowl (BRADLEY 1950; LAKE 1957; MARVAN 1969; TINGARY 1971; KING 1979), the turkey (Hess et al. 1976; HESS \& THURTON 1977), and the guinea fowl (AIRE et al. 1979), with emphasis on this system's macroscopic anatomy and functional aspects.

The morphological study of the reproductive system of Brazilian birds is relatively recent and reflects a growing concern with the potential health risks to which our population may be exposed due to its increasingly closer interaction with dove species such as the Columbina talpacoti Temminck, 1881, which are known to be the carriers of many diseases.

This work was carried out in continuation of the studies conducted on Columbia livia Gmelin, 1879 (MARUCH et al. 1995, 1996). Its purpose is to describe the histology and histochemistry of the male reproductive organs of Columbina talpacoti, as a contribution toward a better understanding of the morphological and functional aspects of the genital system of the male Columbiformes. Such information could also provide a basis for more ample discussions on the reproduction of differents species of Brazilian birds.

1) Morphology Department, Institute of Biological Sciences, Federal University of Minas Gerais. Belo Horizonte, Minas Gerais, Brazil.

Correspondence to: Rua Padre Silveira Lobo 595, 31270-740 Belo Horizonte, Minas Gerais, Brasil. 


\section{MATERIAL AND METHODS}

Eight Columbina talpacoti males captured in Belo Horizonte, State of Minas Gerais, were sacrificed and subjected to a longitudinal median ventral incision to allow an anatomotopographic study of the reproductive system and subsequent dissection of the genital tract.

For the histological study, fragments of the genital tract were fixed in Bouin and Helly fluid (LILLIE \& FULMER 1976), embedded in paraffin and processed in accordance with the usual histological techniques: Gomori's trichromic method and staining with hematoxylin/eosin and azan; Weigert's method (modified by NOGUEIRA \& RIBEIRO 1980) for elastic fibers; and Gomori's technique (GOMORI 1952) for reticular fibers.

For the histochemical study, the periodic acid Shiff (PAS) technique and staining with Alcian Blue (AB) at pH 0.5 and 2.5 (LILLIE 1954) were used to show the glycogen and mucosubstances in epithelial lining cells.

The results were analyzed and photographed on a Leica ACT 2.000 microscope.

\section{RESULTS}

The sperm ducts of the Columbina talpacoti dove start inside the testicle, through the opening of the seminiferous tubules into the retes tubules. Thin-walled and lined with simple cubic epithelium, the retes tubules open into the rete testis, which consists of large cavities or cisterns with a thin wall and simple cuboidal epithelial lining. No morphological variations in the retes tubules were observed between the specimens studied. The rete testis extends from inside the testicular albuginea to the epididymal region (Figs 1,2 ), which is located dorsolaterally to each testicle. It is wrapped by a capsule of ordered, dense connective tissue, which is thicker in adult males. The epididymis is made up of a part of the rete testis, the efferent ductuli, connecting ductuli, and epididymal duct, all immersed in greatly cellular, vascularized, dense connective tissue interspersed with scarce smooth muscle fibers. The morphological aspects of the rete testis (Fig. 3) in its epididymal region are similar to those observable in its intra-testicular portion.

With a thicker wall, the efferent ductuli (Figs 3,4) have folds lined with epithelium that varies from simple prismatic (in three of the males studied) to pseudo-stratified (in the others), with ciliated cells, non-ciliated cells possessing cytoplasmic projections, and basal cells. The epithelial cells are AB and PAS negative. Beneath the epithelium is a layer of considerably cellular, loose connective tissue, with delicate collagen fibers, few elastic fibers, and more abundant reticular fibers. Underlying the connective tissue are smooth muscle fibers organized in circular bundles.

The wall of the connecting ductuli (Fig. 4) is thicker than that of the efferent ductuli. It has no folds and the lumen is large and regular in shape, in all specimens studied. The epithelial lining is pseudo-stratified, with a predominance of ciliated cells with $\mathrm{AB}$ and PAS negative cytoplasmic granulation and a basal nucleus. The 


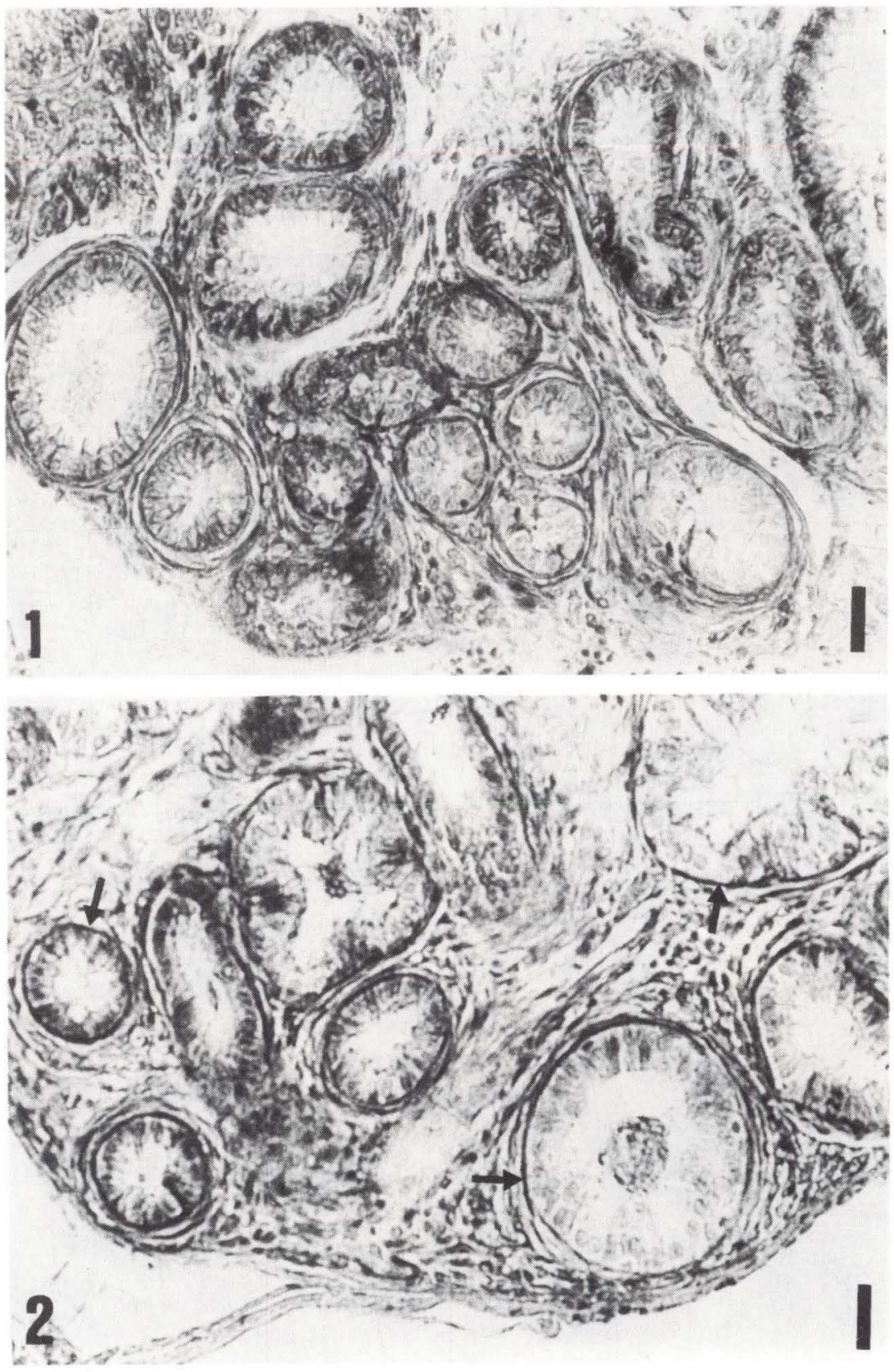

Figs 1-2. (1) Histological appearance of the epididymal region of Columbina talpacoti (Gomori's trichromic method, bar $=0,5 \mu \mathrm{m}) ;(2)$ histochemical aspects of the epididymal region showing the ductuli with PAS + basement membrane $(\rightarrow)$ (PAS, bar $=0,5 \mu \mathrm{m})$. 


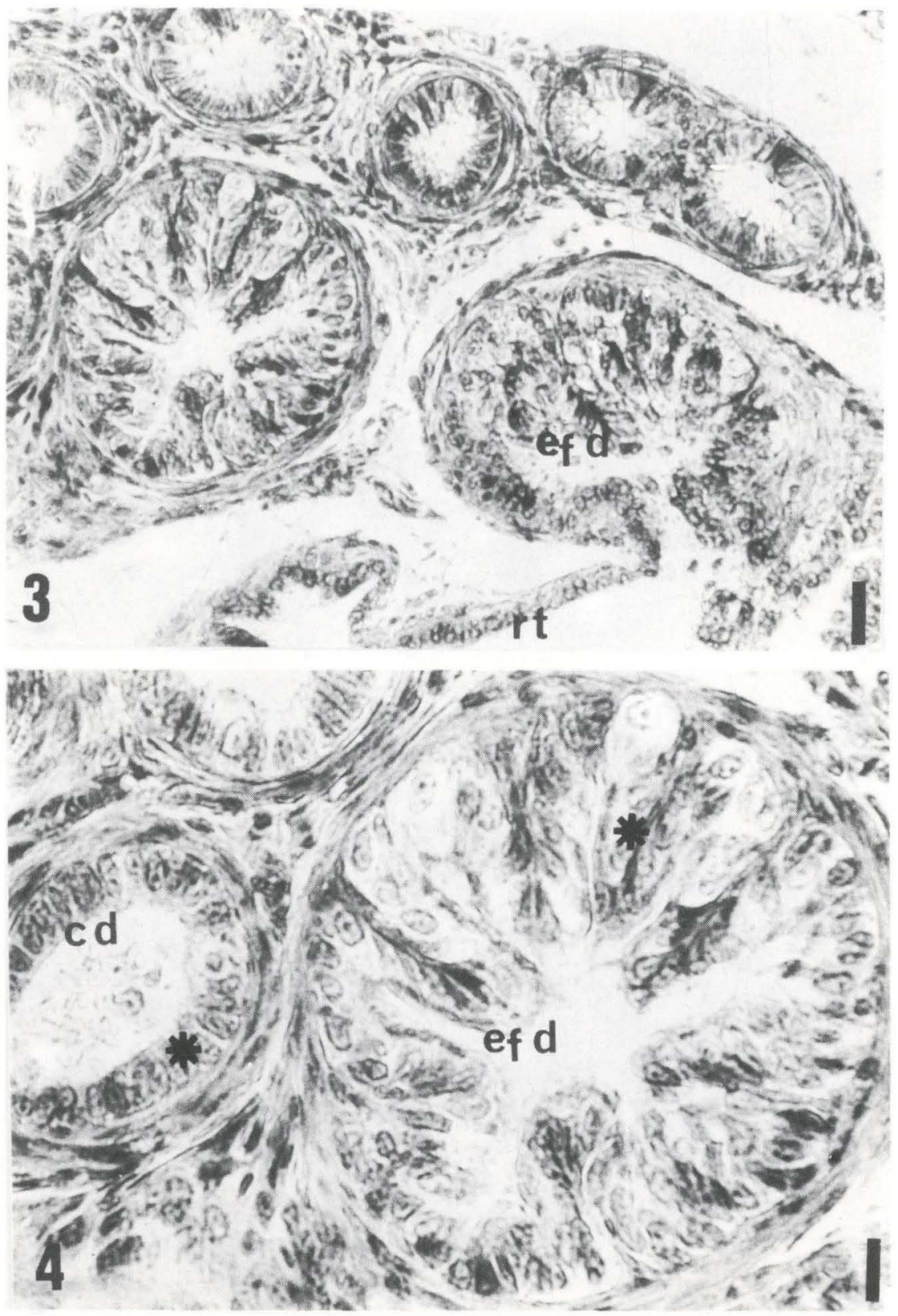

Figs 3-4. (3) Histological aspects of the rete testis (rt) of Columbina talpacoti ending in the efferentes ductuli (ef d) (bar= $0,5 \mu \mathrm{m})$; (4) higher magnification of transverse sections of the efferentes ductuli (ef d) and connecting ductuli (cd) showing histological aspects of the ephitelium that characterizes these ductuli (bar $=0,25 \mu \mathrm{m}$ ). Gomori's trichromic method. 
basal cells have a spherical nucleus, with denser chromatin and an evident nucleolus. The other layers of the wall are morphologically similar to those described for the efferent ductule.

Short and tortuous, the epididymal duct (Fig. 5) starts at the confluence of the efferent ductuli and continues caudally with the ductus deferens. Its thick, creased wall delimits a narrow lumen in its cranial portion, which widens out in the caudal portion. The epididymal duct is lined with pseudo-stratified epithelium composed of $\mathrm{AB}$ and PAS negative non-ciliated cells with cytoplasmic projections and basal cells with a spherical nucleus, vesicules and an evident nucleolus. The tissue adjacent to the epithelium has characteristics that are typical of loose connective tissue. Externally, the muscle tunic, with no distinction between its two layers, is observed.

Starting as a continuation of the epididymal duct, the ductus deferens of Columbina talpacoti (Fig. 6) has a wide diameter and (in most of the males studied) contains spermatozoids. Histologically, its wall is thin, consisting of the mucous, muscle and serous tunics. The epithelial lining is pseudo-stratified, with prismatic and basal cells. The prismatic cells are acidophilous, with a vesiculous, spherical or elongated nucleus and one or two evident nucleoli. Irregularly shaped cytoplasmic projections, similar to stereocilia, are found in the apical pole of these cells, extending toward the opening. The basal cells are smaller, with a spherical nucleus and more condensed chromatin. The basement membrane is PAS-positive and its lamina propria, of considerably cellular and well vascularized loose connective tissue, shows fine collagen fibers, abundant reticular fibers, and few elastic fibers. The muscle tunic is composed of irregularly distributed smooth muscle fibers, without a defined disposition (in all specimens studied). The adventitia tunic is made up of loose connective tissue containing blood vessels and nerve fascicles.

The receptacle of the ductus deferens, a small sacular dilatation, is often observed in the distal portion of the ductus deferens, close to the cloaca. It is lined with pseudo-stratified epithelium composed of prismatic and basal cells and presents a well developed muscle layer.

The opening of the ductus deferens into the urodaeum is through the papilla, a short, rectilinear structure lined with pseudo-stratified epithelium composed of prismatic, caliciform and basal cells.

\section{DISCUSSION}

The studies of the intra and extra-testicular sperm ducts of birds have disclosed a general pattern of morphological organization, even though a consensus has not yet been reached as to the identification and naming of certain segments.

Contrary to what was described by TINGARY (1971) in the domestic fowl, AIRE et al. (1979) and MARUCH et al. (1996) report the presence of retes tubules as a continuation of the seminiferous tubules inside the testicle in the guinea fowl and in doves, respectively, an observation which was also made in the case of Columbina talpacoti. 

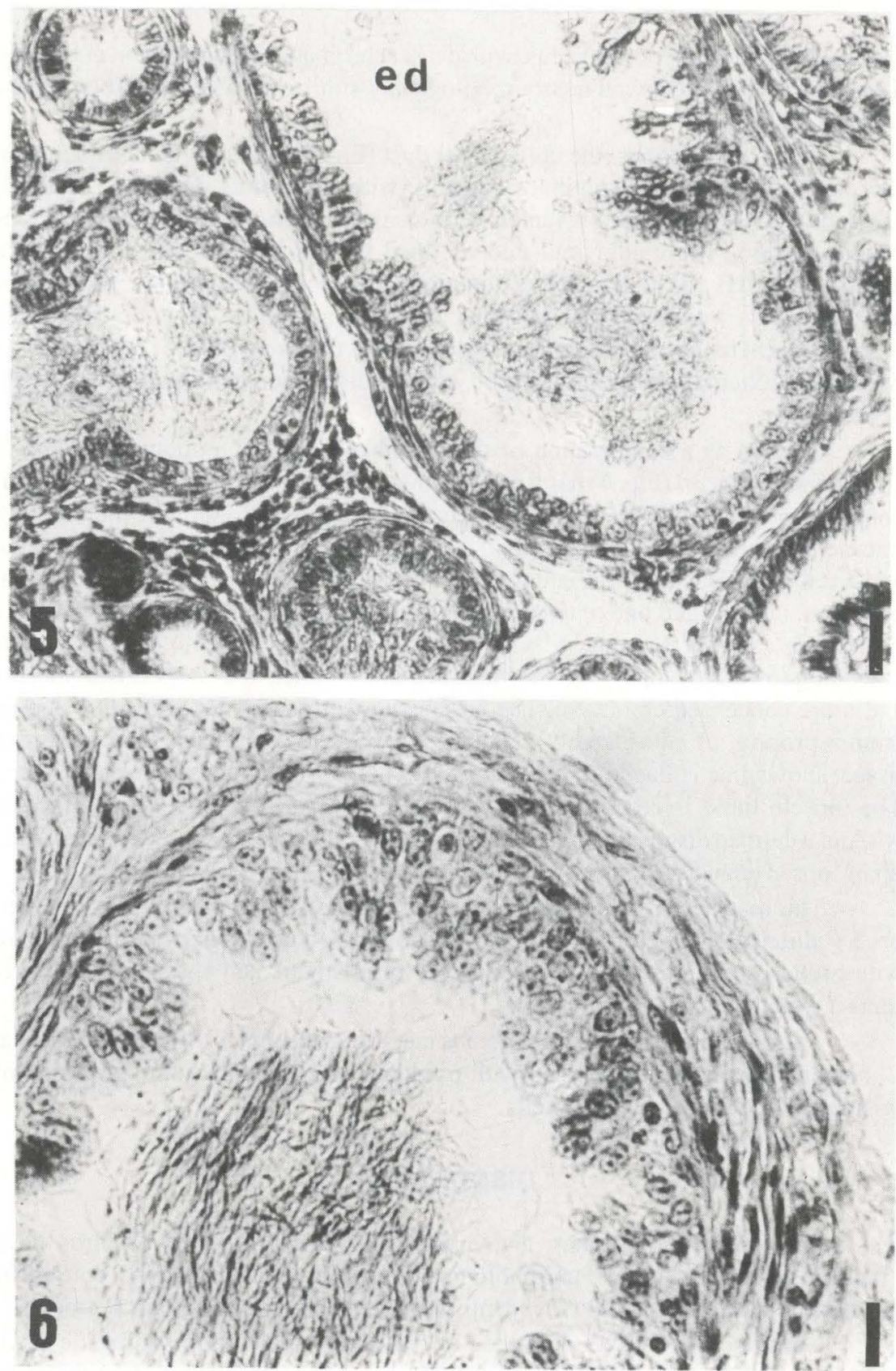

Figs 5-6. (5) Histological aspects of transverse sections of the epididymal duct (ed) (bar= $0,5 \mu \mathrm{m}) ;(6)$ high magnification of transverse sections of the defferent duct (bar $=0,25 \mu \mathrm{m}$ ). Gomori's trichromic method. 
The fact that the rete testis leaves the testicle and connects with the epididymal area, as was observed in Columba livia (MARUCH et al. 1996) and in Columbina talpacoti, is another aspect which contrasts to what is reported in the literature.

The structural combination formed by the rete testis, ductus efferens and epididymal duct was named epididymis by GRAY (1937), BRADLEY \& GRAHAME (1960), MARVAN (1969) and BUDRAS \& SAUER (1975).

STOLL \& MARAUD (1955) and TINGARY (1971) in the domestic fowl, Hess \& THURSTON (1977) in turkeys, and AIRE et al. (1979) in the guinea fowl, refer to it as the epididymal area. In Columbina talpacoti, as in Columba livia (MARUCH et al. 1996), the term epididymal area refers to the system formed by the rete testis (extra-testicular portion), efferent ductuli, connecting ductuli, and epididymal duct.

The efferent ductuli start in the testicular system (BUDRAS \& SAUER 1975) and continue with the connecting ductuli. The epithelial lining, which in the rete testis is simple and pavimentous, in the efferent ductuli becomes pseudo-stratified, prismatic, with ciliated, non-ciliated and basal cells. Two types of non ciliated cells are described by AIRE (1980) in the guinea fowl: type I cells, which have a brush border formed by ramified microvilli, and type II cells, which are smaller and have a smooth surface. The ciliated cells, in addition to the typical cilia, show a small quantity of short microvilli. In Columba livia (MARUCH et al. 1996) and in Columbina talpacoti, the apical projections observed in the non-ciliated cells are similar to stereocilia.

The epithelial lining of the connecting ductuli is similar to that of the efferent ductuli, although in the male guinea fowl (AIRE et al. 1979) no ciliated cells are observable.

The epididymal duct is not divided into head, body and tail. Its epithelial lining is pseudo-stratified and consists of non-ciliated and basal cells in the domestic fowl (LAKE 1957, 1981; TINGARY 1971), turkey (HESS et al. 1976; HESS \& THURSTON 1977), guinea fowl (AIRE et al. 1979), dove (MARUCH et al. 1996), and Columbina talpacoti.

According to LAKE (1957) and HOFFMAN \& VOLKER (1969), the ductus deferens widens progressively in diameter along its median and caudal portion (MARVAN 1969; TINGARY 1971; Aire et al. 1979). Its wall is lined with pseudostratified epithelium composed of prismatic and basal cells. In doves (MARUCH et al. 1996) and in Columbina talpacoti, the prismatic cells have cytoplasmic projections similar to stereocilia, which extend toward the lumen of the duct. Hess et al. (1976) in turkeys, and AIRE et al. (1979) in the guinea fowl, found small projections which resemble vesicles on the apical surface of these cells.

Caudally, the ductus deferens dilates to form the receptacle of the ductus deferens and, according to TINGARY (1971) and HESs et al. (1976), opens into the urodaeum of the cloaca through a small papilla which, in the domestic fowl, is referred to by LAKE (1957) and TINGARY (1971) as an "ejaculatory duct".

The scarcity of data in the literature that would permit a more ample comparison between different bird species indicates the need for the studies to 
continue, so that the morphology and physiology of the male genital tract of birds species native to or introduced in Brazil can be better known.

ACKNOWLEDGMENTS. The authors thank Prof. Ney Eny Demas Carnevalli, for the confirmation of the species under study; biologist Sandra Resende Lima, responsible for the technical preparation of the material studied; and photo lab technician Ivone Carmo de Oliveira. They are also grateful to PRPq/UFMG and FAPEMIG, for their financial support.

\section{REFERENCES}

AIRE, T.A. 1980. The ductuli efferentes of the epididymal region of birds. Jour. Anat. 130 (4): 707-723.

AIRE, T.A.; J.S. AYENI \& M.O. Olowo-OKORUn. 1979. The structure of the excurrent ducts of the testis of the guinea-fowl (Numida meleagris). Jour. Anat. 129 (3): 633-643.

BRADLEY, O.C. 1950. The reproductive organs, p.57-70. In: O.C. BRADLEY (Ed.). The structure of the fowl. London, J.B. Lippincott Company, 185p.

BRADLEY, O.C. \& O. GRAHAME. 1960. The structure of the fowl. London, A.C. Black, 143p.

BUDRAS, K.D. \& T.SAUER. 1975. Morphology of the epididymis of cock (Gallus domesticus) its effect upon the steroid sex hormone synthesis. Anat. Embryol. 148: 175-196.

GRAY, J.C. 1937. The anatomy of the male genital ducts in the fowl. Jour. Morphol. 60: 393-405.

GOMORI, G. 1952. Microscopic histochemistry principles and practice. Chicago, University of Chicago Press, 277p.

HEss, R.A. \& R.J.THURSTON. 1977. Ultrastructure of the epithelial cells in the epididymal region of the turkey (Meleagris gallapavo). Jour. Anat. 124 (3): 765-778.

Hess, R.A.; R.J. Thurston \& H.V. BielLIER. 1976. Morphology of the epididymal region and ductus deferens of the turkey (Meleagris gallapavo). Jour. Anat. 122 (2):241-252.

Hoffmann, G. \& H. VolKer. 1969. Anatomia Y fisiologia de las aves domesticas. Zaragoza, Acribia, 189p.

KING, A.S. 1979. Systema urogenitale, p.289-335. In: J.J. BAUMEL; A.S. KING; A.M. LUCAS; J.E. BREAZILE \& H.E. EvanS (Eds). Nomina anatomica avium: an annotated anatomical dictionary of birds. New York, Academic Press, $377 \mathrm{p}$.

LAKE, P.E. 1957. The male reproductive tract of the fowl. Jour. Anat. 91: 16-129. 1981. Male genital organs, p.1-102. In: A.S. KING (Ed.). Form and function in birds. London, Academic Press, II+678p.

LiLLIE, R.D. 1954. Histopathologic technic and pratical histochemistry. Nova York, The Blakiston Company, 501p.

LILliE, R.D. \& H.M. FULMER. 1976. Histopathologic technic and practical histochemistry. New York, Mc Graw-Hill, 942p.

MarUCH, S.M.G.; M.E.O. Teles \& M.G. RibeIRo.1995. Morphological study of 
the testes of the dove Columba livia (Gmelin) Columbidae-Columbiforme. Revta bras. Zool. 12 (1): 145-150.

Maruch, S.M.G.; M.E.O. Teles \& M.G. Ribeiro.1996. Estudo morfológico e histoquímico das vias espermáticas intra e extra-testiculares de Columba livia (Gmelin, 1879) Columbidade-Columbiformes. Rev. Bios 3 (4): 23-30.

MARVAN, F. 1969. Postnatal development of the male genital tract of the Gallus domesticus. Anat. Anz. 124: 443-462.

NogueirA, J.C.\& R.D. RibeIRo. 1980. A simplified Weigert's method for staining elastic fibers. Arq. Esc. Vet. Univ. Fed. Minas Gerais 32: 333-335.

Stoll, R. \& R. Maraud. 1955. Sur la morphogenése de l'epidide du coq. C. R. Soc. Biol. 149: 1265-1268.

TINGARY, M.D. 1971. On the structure of the epididymal region and ductus deferens of the domestic fowl (Gallus domesticus). Jour. Anat. 109 (3): 423-435.

Recebido em 28.II.1997; aceito em 14.V.1998. 